\title{
Interpretacija i metodički pristup pjesmi The Song of Wandering Angus Williama Butlera Yeatsa
}

\author{
Dean Slavić*
}

\begin{abstract}
Sažetak
Članak tumači životopisne okolnosti nastanka i obilježja ustroja pjesme iz naslova. Interpretacija govori o elementima ljubavne poezije, potrage, konzumacije i rastanka u tumačenu tekstu, a naglašena je promjena značenja nastala mijenom naslova. Glede ustroja, istaknut je smisao opetovnosti riječi (floor, hazel, lands...) te njihova povezanost sa Staigerovim tumačenjem lirike. Objašnjena je uloga broja osam, svijetlih simbola i simetričnosti u sustavu magijskoga priziva. Tekst raspravlja i o stavu ženskoga elementa u pjesmi. Metodički pristup preporučuje motivacije čitanjem učeničkih sastavaka na temu povezanu s epigrafom iz Shakespeareove drame Antonije i Kleopatra. Prikaz osjećaja kazivača i s time povezane modulacije uz svaki stih pjesme koristan je pri interpretativnom čitanju. Tumače se i rasprave, učenički eseji ili pjesme u prozi o stavu djevojke.
\end{abstract}

Ključne riječi: William Butler Yeats; The Song of Wandering Angus; životopis; ustroj; simetrija; metodički pristup

"Slaba je ljubav koja se dade izračunati." Shakespeare: Antonije i Kleopatra

Uvod

Cilj je članka pokazati da Yeatsova pjesma u sebi obuhvaća obilježja triju temeljnih vrsta ljubavne lirike. Tekst dokazuje i da je lirika iz naslova puna različitih obavijesti, ali je cjelovit, koherentan i jasan tekst. Pjesma je ostvarila i autorova nastojanja oko sažimanja nacionalnih, osobno-emocionalnih i religijskih interesa. Uporabljena su načela imanentne kritike i orijentacije na sam tekst, ali također pokazujemo da nema teksta bez konteksta, pa pjesnikov životopis valja poznavati i uključiti u argumentaciju.

* Prof. dr. sc. Dean Slavić, Filozofski fakultet Sveučilišta u Zagrebu. Adresa: Ivana Lučića 3, 10000 Zagreb, Hrvatska. ORCID iD: https://orcid.org/0000-0002-5168-1956.

E-adresa:dean.slavic@gmail.com 
William Butler Yeats rođen je 13. lipnja 1865. u Dublinu (Coote, 1997, 3), a obitelj se najprije nastanila u skromnoj kući u Sandymount Avenue. Rođenje određuje budućega pjesnika, ali po načelu suprotnosti, ili jedinstva u diobi, kako je naglasila kritika (usp. Sanesi, 1974, 13). Obitelj pokazuje duhovne otklone koje sinovi čine u odnosu na svoje očeve. Pjesnikov djed William Yeats bio je protestantski svećenik, a pjesnikov otac John Yeats postao je ateist (usp. Sanesi, 1974, 13). Sam pjesnik prihvatio je put koji ga je učinio sličnim i različitim u odnosu na pretke. Književnik Yeats prihvaćao je magijske obrede temeljene na vjeri u stare keltske bogove. Božanska obitelj Tuatha Dé Danann s bogovima Lughom, Ogmom i konačno Angusom — koji je dao ime govorniku ovdje tumačene pjesme - postala je bitnom za Yeatsovo stvaralaštvo. Pjesnik o svojim stavovima piše u eseju Magic, gdje tumači sposobnosti pohranjene u čovjeku koje magijski obredi mogu probuditi i razviti. Interes za magiju nije samo teoretski, nego je i praktičan. Društvo Zlatna zora, koje je pjesnik vodio, bavilo se je magijom na praktičan način, naime izvodilo je obrede kojima je prizivalo duhove i stare bogove te nastojalo utjecati na zbilju (Clark, 1965, 59). Magijska praksa pružala je Yeatsu, uz ostalo, sadržaj i metafore za poeziju.

William Yeats tako je zadržao bliskost s vjerom i određenim oblikom duhovnosti, što je imao njegov djed, ali i s otcem, koji nije pripadao kršćanskoj vjeroispovijesti. Yeatsov je stav zanimljiv i na razini cjelokupne kulturne scene. Prošlo stoljeće poznaje uglavnom intelektualce koji pripadaju velikim religijama, ili se određuju ateistima, agnosticima i indiferentistima. Yeats sa svojim svjetonazorom nije mogao računati na potporu utjecajnih vjerskih, odnosno nevjerskih krugova, pa se je morao probijati osamljen. Takva osoba zasigurno ima simpatije onih koji ne smatraju da je nedvojbena pripadnost "našima" prijeko potrebna za uspjeh. Ne treba u tom biti ni odveć naivnim, jer je činjenica da je pisao engleski povoljno utjecala na književnikov uspjeh.

Obitelj je odredila budućega pjesnika i u smislu novčanoga položaja, točnije to je učinila očeva odluka. Usprkos tomu što je završio pravni fakultet i komunicirao s utjecajnim ljudima iz svojega naraštaja, John Yeats odlučio se je posvetiti slikarstvu. Posljedice su bile teške za budućega pjesnika, njegove dvije sestre i brata, pa i za same roditelje. Obitelj se je selila iz Irske u London i opet u Irsku, a pjesnik je bio primoran na vrlo oprezan život. Bez pomoći mecene, lady Auguste Gregory, stvarao bi još mukotrpnije.

Nacionalne su odrednice od početka nedvojbene, ali opet nisu uobičajene za tumačeni prostor i vrijeme. Yeats je bio po obiteljskom nasljeđu protestant $u$ rimokatoličkom okružju, ali se je također osjećao Ircem među Englezima (Coote, 1997, 25). Budući je pjesnik brzo uvidio nepravde koje je britanska uprava činila irskomu narodu. Stalan kontakt s nižim stališem, a zatim dodir s patnjama i legendama irskih ljudi, učinio je dio posla u odredbi nacionalne pripadnosti. U mjestu Sligo na zapadnoj irskoj obali majčina je šira obitelj posjedovala imanje. Tu je budući pjesnik živio u doba prvoga djetinjstva, ali je i nakon toga provodio ljeta na imenovanom području. Za Yeatsa su živopisna obala, seljaci i njihove pripovijesti, ljeta i ukupan krajobraz bili znakom raja na zemlji. Ribolov, koji je 
bitan motiv u ovdje tumačenoj pjesmi, dio je toga svijetloga i uskoro izgubljenoga zavičaja.

Odlazak u London, poglavito u osnovnu školu Godolphin u Hammersmithu 1877., bio je izvor nesreća. William Yeats nije volio gradsko okružje, a drugi su se učenici rugali njegovu irskomu naglasku. Obitelj je 1880. opet u Irskoj, autor je od 1881. polazio gimnaziju u Dublinu te u istom gradu Metropolitan School of Art od godine 1884.

Za nacionalno osvješćivanje presudna je vjerojatno bila godina 1885 . Profesor Charles Hubert Oldham sa sveučilišta Trinity sazivao je prijatelje i znance u svoje prostorije subotom uvečer, a skupljeni su umnici tvorili The Contemporary Club. Intelektualci su raspravljali o povijesti i budućnosti irskoga otoka, općim okolnostima u Britanskom Imperiju i svijetu, o umjetnosti i politici. Pjesnikov je otac uglavnom portretirao sudionike susreta, ali je njegov sin živo sudjelovao u razgovorima. U siječnju 1885. John O’Leary, jedan od vođa pokreta za samostalnost, vratio se je u Dublin nakon 19 godina zatvora i prognaništva. Dopustio je Yeatsu da studira knjige iz njegove knjižnice posvećene irskoj povijesti, mitovima i legendama. Istaknuta osoba irskoga pokreta shvatila je da je mladi Yeats jedina osoba u krugu koja će u budućnosti biti držana genijem (Coote, 1997, 50). U tom krugu William Butler Yeats postao je čvrstim irskim domoljubom, što mu je naravno donijelo odbojnost na drugoj strani. Vladajuća elita u kulturi i politici, naklonjena jedinstvu s britanskom krunom, za njega je postala zatvorenom, a on sam trpio je određenu izoliranost (Coote, 1997, 293).

Yeats je nastojao povezati irske domoljubne osjećaje, svoju vjeru i osobnu ljubav prema ženi s književnim poslom. Pjesma koju govori irski bog ljubavi Angus dio je toga životnoga projekta. Prema keltskoj svetoj pripovijesti, Angus naime luta po Irskoj, zadržava se najviše na obali rijeke Boyne, a cjelovi toga božanstva postaju pticama koje lebde oko djevojaka i mladića. Uvodeći te simbole u svoju pjesmu na skladan način, Yeats postiže jedinstvo.

Da bismo shvatili bitan ljubavni čimbenik Yeatsova života, koji on kako smo vidjeli želi u svojoj poeziji povezati s ostalima, moramo se usredotočiti upravo na osjećaj koji bog Angus predstavlja, a to je ljubav prema ženi. Naravno da u tim domovinskim, duhovnim i ljubavnim svezama vidimo trag bliskosti Danteu i njegovoj Beatrice. Ženska osoba koja je Yeatsa nadahnula za ovdje interpretiranu pjesmu zvala se Maud Gonne, a njezin je otac bio Englez i britanski pukovnik, pa je s njim putovala po Europi. Djevojka je uočila tegobe siromašnih irskih seljaka koje su nesmiljeno izbacivali iz koliba kad gospodarima zemlje nisu donosili dobiti, i kad im je stoka postala probitačnijom od ljudi (Coote, 1997, 81). Otac Tommy sam je uvidio da njegova vojska zlorabi silu, i u određenoj je prigodi zadržao svoje vojnike u vojarni kad su domoljubi marširali gradom. Napustio je službu i pristupio stranci koja se je zalagala za Home Rule, samoupravu irske zemlje.

Zbog niza okolnosti Maud Gonne mogla je učiniti puno za irsku stvar. Bila joj je dana naglašena ljepota, organizacijska inteligencija, nadarenost za glumu i govor te velika količina energije. Prije punoljetnosti napustila je očevu obitelj i počela zarađivati za život glumom. Engleska plemkinja postala je irskim oružjem 
u borbi za samostalnost. Britanske vlasti počele su u to doba progoniti siromašnu irsku djecu zato što su uzimali šiblje ili slamu da bi se zgrijali. Nadalje, nasilno su izvlačili žene iz koliba za koje nisu mogli plaćati najamnine, dok su one stiskale krunice u ruci. Mlade majke utapale su se u jarcima unesrećene. Maud Gonne pojavila se kao lijepa i moćna spasiteljica: pozivala je novinare, sklanjala žene u svoju hotelsku sobu i dijelila obroke juhe (Coote, 1997, 85). Pomagala je tijekom parlamentarnih izbora i njezina aktivnost zaslužna je za ondašnju pobjedu irskoga kandidata (Coote,1997, 79). Živeći između Londona, Pariza i Irske, strasno je promicala irsku nezavisnost. Za ostvaraj toga cilja, govorila je, dopušteno je rabiti i nasilje, što je bio stav kojim je znala u to doba šokirati i same irske domoljube.

Visoka stasa i velikih očiju, zavidno pravilna lica, inteligentna i nadarena, Maud Gonne ušla je u siječnju godine 1889. u kuću u Bedford Parku u Londonu — gdje je u to doba skroman iznajmljeni stan imala obitelj Yeats. Pjesnik je ovako opisao susret: "prošla je kraj prozora i popravila kiticu cvijeća koje je bilo u vazi. Dvanaest godina poslije pisao sam o tome dojmu u stihovima. Osjećao sam blizinu velike dobrostivosti, hrabrosti i nemirna duha, a kad je ona otišla, sa svim pticama koje su pjevale, moja zamišljenost nije bila samo zamišljenost koju pruža ljubav. Mislio sam da je sve to neka vrsta vidovita opažanja, ali je zapravo bilo, sad to mogu vidjeti, očitovanje nesreće koja je uskoro slijedila « (Yeats, 1989, 511). ${ }^{1}$

Bog Angus s pticama već je tu neizravno prisutan, a biograf Coote ovako govori o susretu: »Mislio je i o Blakeu, jer je vidio da Maud Gonne ima najvišu vrstu ljepote, stoga što se najmanje mijenja s vremenom. No, iako je Maud mogla biti izraz starih uzora, rumenilo njezine puti činilo ju je stvarno nazočnom u sadašnjosti. Yeatsa je podsjetilo na rascvalu granu jabuke, koja je bila u vazi u sobi, iako je vjerojatno riječ o pogrješnoj uspomeni, jer je bio tek siječanj« (Coote, 1997, 80; usp. Rudd, 1953, 144).

O motivu jabuke, nazočne u pjesmi koju tumačimo, vjerojatno je u pravu Mazzari, koji navodi D’Arbois Youbanville i Mythologie Irlandaise, knjigu koju je Yeats poznavao: jabuka je nazočna u nizu galskih i grčkih pripovijesti. Yeats rabi motiv u djelu The Wanderings of Oisin, objavljenom prije susreta s Maud Gonne (Mazzari, 1957, 342). Tako bi i autobiografski zapis zapravo bio pod utjecajem literature.

Eliotove su riječi svakako poučne: „Druga vrsta neosobnosti pripada pjesniku koji iz jakoga osobnoga iskustva može izreći opću istinu; zadržavajući sve posebnosti svojega iskustva, sposoban je od njega napraviti opći simbol.“ (Eliot, 1975, 251).

\section{Bibliografski podatci}

Pjesma je prvi puta objavljena u The Sketch 4. kolovoza 1897. godine. Naslov joj je bio $A$ Mad Song. Poslije je ušla u knjigu The Wind among the Reeds (1899.

1 Izvornik je djelo Memoirs objavljeno 1972., ur. Denis Donoghue. 
"Vjetar u trsci"), ali s bitno drugačijim naslovom: The Song of Wandering Angus. Promjena naslova duboko utječe na značenje pjesme.

\section{Potraga, užitak i rastanak}

Ljubavne pjesme možemo svrstati u neku od triju skupina: potraga ili snubljenje, užitak ili konzumacija, koja daje neku vrstu epitalamija, te rastanak ili smrt ljubavi. Marvell pjesmom To His Coy Mistress ("Sramežljiva draga") izvrsno predstavlja prvu skupinu: da imaju beskrajno puno vremena, kaže subjekt dragoj, mogao bi čekati na njezine čari dok se ne obrate židovi. Johne Donne i pjesma Svojoj gospi koja ide u postelju (»Kraljevstvo moje, tek s jednim stanovnikom«) jasan je ostvaraj druge skupine. Rastanke mogu predstavljati Katul s »Jadni Katule, ne nadaj se više«, Šimić s »Kraj ljubavi u duši mrtvo zvoni« te Vesna Parun s velikodušnom »Ti, koja imaš nevinije ruke«.

Yeatsov tekst sadrži motive potrage i rastanka, a ima i jasnih iako specifičnih tragova konzumacije.

Motivi djevojke koja bježeći odlazi i nestaje kroz blistav zrak (»and ran / and faded through the brightening air«) govore o rastanku. Činjenica da je subjekt u najvećem dijelu teksta bez nje, pa je tako i u času dok govori svoju pjesmu, također doprinosi ugođaju rastanka. Kazivač se tek nada da je ta razdvojenost privremena.

Potraga daje tomu tekstu najviše simbola, a podijeljena je na dvije bitno različite vrste. Sve što subjekt čini do pojave djevojke nije upravljeno tomu da nađe ljubav, nema namjere njezina pronalaska. On ide u ljeskovu šumu, odsijeca ljeskovu šibu i stavlja jagodu na povraz. Sprema se na ribolov, istina pomoću neobična pribora, no nema znakova koji bi govorili da je riječ o ljubavi koja će doći. Ona mu stiže kad se tomu ne nada i iznenađuje ga svojom čudotvornom preobrazbom. S druge strane, poznavatelje keltske mitologije na ljubav upozorava samo ime lutalice Angusa iz naslova, jer je to ime nosio bog ljubavi. Leptiri mogu biti prefiguracija ptica s kojima se bog obično prikazuje, a njihova metaforična blizina zvijezdama najava je stvarno-magijske preobrazbe pastrve u djevojku.

Druga vrsta potrage, ona s namjerom, sa subjektove strane počinje nakon njezina nestanka. Riječ je i o starom uzorku po kojem muško biće mora slijediti ženu koja stvarno ili tobože odugovlači. No, potraga tu traje doista dugo: u času kad govori pjesmu subjekt je već u godinama, i očito je ostario upravo tražeći svoju ljubav. Dapače mu je to prvi i jedini izraz koji kazuje u času kad se vrijeme iskaza i vrijeme djelatnosti podudaraju: »Though I am old with wandering / Through hollow lands and hilly lands«. Izraz zaslužuje pozornost: riječ je o potrazi kroz bregove i doline, dakle je prošao mnoge zemlje, što je prostorna istovrjednica vremenski duge potrage. Ali, izraz hollow lands, shvaćen sam po sebi, barem začas, govori i o pustoši. Kazivačev je život pustoš jer u njemu nema ljubavi. Takva pustoš podsjeća i na Eliotovu pjesmu Pusta zemlja, također ispunjenu ljubavnim motivima, i objavljenu skoro dvadeset i pet godina nakon Yeatsove pjesme. 
Jedino što bi kazivača Angusa moglo spasiti iz pustoši bila bi djevojka koju voli, i stoga je to prije svega pjesma potrage. Prazninu bi tako ispunili plodovi jabuke, koji će se brati na kraju.

Tražeći, subjekt uvelike zamišlja buduću sreću, pa stoga imamo i motive bliske konzumaciji. Prvi puta djeluju u već tumačenu času kad se pojavljuje djevojka, točnije kad se pastrva preobražava u mladu ženu. Izrazi glimmering girl ("blistava djevojka") i apple blossom ("jabukov cvat") nose tragove užitka koji kazivač osjeća pri svojem iskazu. Asonancije i aliteracije, ovdje, pojačavaju osjećaj sreće u opetovnosti suglasnika /g/,/l/,/r/; /p/, /l/, /b/, /l/, te u ponavljanju vokala /i/. Vrhunac je toga užitka simbol u kojem ona zove kazivača po imenu. Svaki muškarac na početku druženja shvaća kao znak naklonjenosti kad ga djevojka koju želi zazove po imenu. Motiv govori i to da ga je ona na neki način prepoznala, da ona sama nije bila iznenađena njegovom pojavom, kako on jest njezinom. Ne možemo znati je li čekala upravo njega, je li sve organizirala i ustvari mu se namjestila, kako bi se to kolokvijalno reklo u hrvatskom jeziku.

Drugi su znakovi konzumacije obilježeni njegovom željom. Kritika spominje u tom smislu poraz, jer mu ona ustvari ne dolazi (Bloom, 1970, 126). Prvi naslov pjesme $A$ Mad Song doista bi sugerirao neuspjeh: ono što subjekt želi jest ludost, njegova je pjesma luđačka i smiješna želja, a sreća se ne će ostvariti. Svi motivi u pjesmi time bi bili natopljeni i ironijom. Činjenica je da se pjesnik odlučio u konačnici govornika približiti bogu ljubavi Angusu, i to bitnim mjestom u naslovu, čime je znatno promijenio smisao. Sada je kazivač jak, blizak je bogu čijoj pjesmi nitko ne može odoljeti, pa ne će ni djevojka za kojom traga. S druge strane, nije nedvojbeno da je kazivač bog, nedvojbeno je samo ime, pa se dio sumnje u uspjeh zadržava.

Subjekt istina tek zamišlja djevojku, a čineći to tako intenzivno, već se vidi s voljenom, pa u tom poetskom snu na neki način biva s njom. Ne treba zaboraviti staru i naivnu magijsku tehniku: živo predoči, vizualiziraj situaciju koju želiš, i ona će ti se ostvariti, poglavito ako to činiš uz izgovor određenih riječi. Pjesma je magijski obred kojim kazivač zaziva ono što voli, i traži da to uđe u njegov život. Šarena trava, poljubac u usta, držanje za ruke, plodovi jabuke koji se beru, sve su to s jedne strane prizivanja, a s druge i ostvaraji sreće.

Događaje u pjesmi prikazala bi ova shema: nenamjerna potraga — susret, nepotpuna konzumacija i rastanak — nova potraga i želja za konzumacijom koja je živo predočena. Prošlost, sadašnjost i budućnost kazivača bivaju određeni prikazanim uzorkom. Sadašnjost je u času kazivanja, koji je bolno označen starošću. Prošlost i budućnost predstavljaju potrage, djelomičan i željeni ostvaraj ljubavi.

\section{Smisao opetovanih motiva}

Više riječi opetuje se u pjesmi, često s malim razmakom. Riječ je o ustaljenom Yeatsovu postupku. Into the Twilight opetuje riječ heart. Antologijska The Lake Isle of Innisfree iz knjige The Rose ponavlja go u prvom stihu prve strofe i peace u prvom stihu druge kitice. When You Are Old u trećoj kitici ima četiri puta preterit 
loved i još jednom love. Kasni antologijski tekst Sailing to Byzantium opetuje sing u drugom stihu druge kitice, treća kitica nosi dva puta riječ fire u rasponu od triju stihova, a završna strofa u drugom i trećem retku ima dva puta riječ form.

Yeatsova se umjetnička sposobnost pokazuje u činjenici što može opetovati riječi bez učinka monotonije. Ponavljanja prate pomaci u smislu, no ona tvore i glazbene ugođaje, koje je moguće protumačiti jedino interpretacijom svakoga mjesta.

U Song of Wandering Angus niz riječi opetuje se s posebnom svrhom, koja nije iscrpljena u glazbenim vrijednostima. Dva puta čujemo riječi hazel, moth/moths, floor, lands, went, berry, fire, silver i time. Riječ apples opetuje se tri puta.

Ponavlja se i cijeli izraz, pa u trećoj kitici imamo najprije »And someone called me by my name«, a četiri stiha dalje »Who called me by my name and ran«. Zamjenica se sada odnosi na djevojku, kazivač je znači u međuvremenu doznao da ga je ona zazvala.

S jedne strane, opetujući riječi, kazivač kao da baja, magijski priziva onu koju voli. Ako su se opetovali noćni leptiri, lješnjak, zemlje i samo vrijeme, onda i izabrana djevojka može opet doći u kazivačev život. Subjekt kao da joj stvara mjesto, uvjerava i sebe i slušatelje da su ponavljanja moguća, pa i ona može opet doći i dijeliti s njim sreću. Oganj je na početku u subjektovoj glavi, ustvari je to vjerojatno vrućica, a zatim ribolovac doista pali oganj u stvarnosti. Tako je i djevojka u drugom dijelu pjesme u kazivačevim mislima, a mogla bi se javiti i u zbilji.

U popis simbola koji se opetuju nismo uvrstili anafore, o kojima posebno govorimo.

Poziv je bitan u tom nizu stoga što je riječ o cijelom izrazu koji dolazi dva puta. Druga je pojavnost naravno različita jer nosi dodanu vrijednost znanja o tome tko govori. Suprotno tomu, on njoj ne će znati ime do kraja pjesme. Znači da je pravi identitet djevojke skriven u času govora. Kako se pastrva preobrazila u djevojku, tako se djevojka može javiti drugi put u novom obliku. Ime ju još nije definiralo.

Pozornost valja posvetiti i motivu jabuke. Na početku se javlja kao cvat u vlasima djevojke. Na kraju su to plodovi koje zajednički beru subjekt i njegova partnerica. Ono što je na početku obećanje, na kraju bi mogao biti ostvaraj, koji može simbolizirati i djecu, ali i pjesme koje će nastajati, te općenito konzumaciju životnoga veselja.

Jabuke upućuju i na još jednu vremensku oznaku, jer na početku imamo cvat, dakle proljeće, a na kraju plodove, znači zrelu jesen. Temporalnost pjesme izrečena je i početkom, gdje čitamo o noći, koja je sjajna od pojave djevojke. Na kraju dolaze dani i noći sugerirani u suncu i mjesecu — ali oni znače i neku vrstu vječnosti u kojoj će se novi susret zbiti — tamo više ne će biti rastanka, ni boli ni smrti.

Opetovnost koja mora zazvati djevojku vidljiva je i u srebrnoj boji. Na početku je srebrna pastrva, na kraju su srebrne jabuke mjeseca koje će zaljubljeni zajednički brati, a povezuje ih djevojka. 
Korisno je istražiti i hod, ili pokret. U prvom dijelu pjesme, u prošlosti u odnosu na vrijeme iskaza, subjekt ide u ljeskovu šumu. U času dok govori on je već dugo vremena lutao, dakle putovao. Na kraju će u budućnosti hodati, ali ovoga puta po šarenoj travi i u društvu svoje voljene.

Pomaci u smislu opetovanih riječi uvjetovani novim surječjima grade znakovito bogatstvo pjesme, koje upućuje prije svega na razvoj.

Opetovnosti iz te rane pjesme dobivaju poseban smisao u surječju ponavljanja, vječnoga vraćanja istoga, koje je pjesnik tumačio u djelu $A$ Vision iz 1925 . i koje bitno obilježuje njegovu umjetnost. Podroban prikaz i primjer interpretacija pjesama i drama, te Nietzscheov izvor, u tom aspektu pruža Stipe Grgas (1989, 69-106). Taj tumač vidi kako po uzorku povijesnoga kretanja, koji je uobličio u $A$ Vision, Yeats drži »da se u historijskom vremenu cikličko smjenjuju razdoblja moći i slabosti, zdravlja i bolesti, vlasti pojedinca i gomile« (Grgas, 1989, 82).

Ovdje tumačena pjesma u mogućem bi drugom dolasku djevojke vidjela nešto očito pozitivno, pa bi donijela i ispunjenost. U kasnijim je pjesmama drugačije, a tumačenja je moguće naći u već navedenoj Grgasovoj knjizi.

\section{Lirska evokacija}

Prizivajući voljenu, subjekt ostvaruje bitno obilježje lirskoga stila kako ga vidi Staiger. ${ }^{2}$ Prožetost subjekta i objekta pjesme više ne postoji ili još ne postoji, a subjekt svojim iskazom upravo to jedinstvo nastoji dostići. Lirski se pjesnik sjeća bivše prožetosti i to jedinstvo priziva, evocira u pjesmi. Po Staigeru riječ je o obostranoj djelatnosti subjekta i prirode, onoga koji pjeva i onoga što zaziva. Teoretičar vidi dvostruku uspomenu, dvojno sjećanje nekoga bivšega sklada koji valja opet prizvati i ostvariti (Staiger, 1946, 63). Trag rečenoga u Yeatsa je činjenica da djevojka na početku zna kazivačevo ime. Ali, nakon njezina nestanka nema znakova koji bi govorili da i ona njega traži ili da ga uopće želi. Svojim riječima subjekt ustvari odgovara na njezin poziv, na imenovanje koje je uslijedilo nakon što se pretvorila iz ribe u djevojku. Ona je Drugo, koje mu pruža jezik, ali i nesreću.

\section{Broj osam}

Sva tumačenja simbola iz ovoga i iz idućih poglavlja, a to bi se moglo reći i za drugo i treće poglavlje, dokazuju da je pjesma koherentna cjelina, naime da tvori čvrst i jasan sustav, usprkos raznolikosti materijala koji je u nju ušao. U striktnom smislu ovdje također govorimo o opetovnostima. Pjesma ima tri oktave, koje se sastoje od osmeraca. Simbolika broja osam biva ovdje znakovitom: »Osam je

2 Pozivamo se na Staigerovo djelo Temeljni pojmovi poetike, što navodimo iz konkretnoga djela. Cijenimo njegove dobro poznate stavove iz knjige Umijeće interpretacije s osnovama imanentne kritike, po kojima se valja usredotočiti isključivo na tekst, no ipak smatramo da je književnikov životopis u kontekstu ovoga članka potrebno poznavati. Nema teksta bez konteksta ili, možda još bolje rečeno, tekst bez surječja je krivotvorina (Carson, 2007). 
uvijek broj kozmičke ravnoteže. To je broj glavnih strana svijeta zajedno sa sporednima [...] Često ima toliko žbica na kotaču, od keltske okrugle kriške do budističkoga kotača zakona [...] Osmi dan dolazi nakon šest dana stvaranja i sabata. On navješćuje buduće vječno doba [...] Osmi dan označuje i promjenu oblika« (Chevalier i Gheerbrandt, 1983, 466).

Broj kozmičke ravnoteže, keltske kriške, vječnoga doba i promjene oblika nije bez dodira s motivima iz Yeatsove pjesme. Tako djelo ispunjava zadatak sažimanja nacionalnih i drugih elemenata i jedan tekst. Djevojka bi omogućila vječnu sreću i dala subjektu ravnotežu i ispunjenost. Sjetimo se da u pjesmi niz motiva dolazi dva puta. Ravnoteža podrazumijeva simetriju, sličnost ili još bolje istovjetnost dviju strana. Simetrija bi bila ostvarena da subjekt nađe djevojku koju traži, da mu ona dođe opet te da početak i kraj imaju stvarnih sličnosti u njezinoj drugoj pojavi. Njezin pronalazak ostvario bi sklad koji broj osam navješta. Svijet koji je uređen sugerira Vrhovno biće koje ga je stvorilo.

\section{Svjetlost i djevojka}

Kritika je opazila bitnost ognja i svjetlosti za pjesmu. »Oganj u glavi iz prve kitice nalazi vanjski izraz u sjajnoj djevojci druge strofe, gdje je užgan na mjestu plamena s ognjišta «(Bloom, 1970, 126). Korisno je napomenuti da nalazimo tragove svih četiriju praelemenata: ognja, vode, zemlje i zraka — koji se također izravno spominje. »Oganj u prirodi, koji pripada suncu i mjesecu, postao je čista vizija, zlatne i srebrne jabuke koje će biti ubrane kad se stigne do Hesperida, kad potraga bude gotova i draga zadobivena« (Bloom, 1970, 126). Mišljenja sam da ti motivi nisu bez dodira s finalnom srećom koja čeka spašene u Otkrivenju, iako kritika to ne ističe.

Spoj svjetlosti na kraju priziva i ljubavni čin: »Važnija je, međutim, simbolika lješnjakova stabla (koje je prema Yeatsovu vjerovanju bilo drvo Života i Znanja) te srebrnih jabuka. Spoj dvaju izvora svjetlosti simbol je ljubavnoga sjedinjena (mjesec kao simbol ženskosti i imaginacije, sunce kao simbol muškosti i intelekta, a jabuka simbolizira sretnu ljubav, ali konotira i edensko drvo spoznaje)« (Gjurgjan, 1995, 296).

U Yeatsovim tekstovima teoretske naravi nalazimo dvije zavojnice, spirale: $\mathrm{u}$ prvoj sunčanoj bivaju prostor, etika i objektivnost, a u drugoj mjesečevoj vrijeme, estetika i subjektivnost (Sanesi, 1974, 37). Pjesnik je o tim simbolima promišljao i izvodio široke antitetske podsjećaje, koji su obuhvaćali muško i žensko, aktivno i pasivno, složeno i jednostavno, kozmopolitsko i nacionalno (Parkinson, 1952, 54). Vidjeli smo da pjesma rabi simbole mjeseca i sunca, a očito su nazočni prostor i vrijeme. Kritika nalazi u simbolima sunca i mjeseca iz Angusove pjesme prvotne Hermesove oznake za muški i ženski element, te nakon navoda posljednje kitice dodaje da će tako dvoje postati jedno, i uživati nagradu ženidbe (Parkinson,1952, 55).

Svjetlost prati djevojku, a činjenica da ona dolazi u noći tvori pozadinu koja suprotnošću naglašava njezin sjaj. Pastrva iz koje će se ona pojaviti biva srebrna 
(silver), ona sama je svjetlucava (glimmering) — time zvukovne podudarnosti govore o kontinuitetu njezine osobnosti. Jabukov cvat također navješćuje svjetlo. Zrak u kojem nestaje biva sjajan, svijetao i jasan (brightening). Svjetlom obilježeni i moćni simboli sunca i mjeseca dobro su povezani s jabukama, a najavljuje ih jabukov cvat iz djevojčine kose.

U prvim dvama kiticama oganj je, već smo rekli, bio u kazivačevoj glavi, a zatim su se pojavili oganj u stvarnosti i sjajna djevojka. Tako je u trećoj kitici djevojka najprije u kazivačevoj pjesmi, a zatim mora doći i u stvarnosti, možda u neizrečenoj i žuđenoj četvrtoj kitici, te time u govornikovoj budućnosti.

\section{Simetrija pjesme s anaforama i rimama}

Desnu stranu pjesme, kraj stihova, obilježuje ukrižana rima, abab, a lijevu stranu u glazbenom smislu naglašavaju anafore. Riječ and uvjerljivo je najučestalija s deset pojavnosti, i inače je prva po frekvenciji u jezičnoj praksi te ne tvori monotoniju. U ovom tekstu riječ naglašeno priziva zajedništvo, prije svega zajedništvo kazivača i ljubavi. Riječ je o novoj potvrdi cjelovitosti i koherentnosti teksta punoga različitih simbola.

Slijedi riječ $I$ (“ja”), a u engleskom je njezina opetovnost manje stilski obilježena no u hrvatskom. Zanimljivo je da se opetuju na početku stihova i riječi sa sličnim glasovima: Though / Through, a imamo i glasovno slične izraze When I / I went. Nizovi anafora ili anaforičnih sklopova s lijeve strane tvore glazbenu protutežu rimama s desne strane, čime se opet naglašava simetričnost. Vjerojatno je pojava poveziva s tumačenim opetovnostima i kazuje da se simetričnost može ostvariti i na razini druge pojavnosti predmeta potrage. Djevojka će opet doći, jer se svi drugi simboli u pjesmi javljaju po dva puta najmanje. Svijet je uređen, jasan i promišljen, ali samo ako se ona opet pojavi.

\section{Položaj ženskoga elementa}

Svi dosad interpretirani simboli — od izravnih iskaza na strateškoj razini novoga susreta do suptilne taktike opetovnosti motiva koji prizivaju voljenu nedvojbeno govore o želji muškoga subjekta. O tom može biti rasprava i dvojbi jedino u smislu toga kako ju on zove i hoće li mu doći. Pogledamo li situaciju sa stajališta ženskoga elementa, znači pastrve i potom djevojke koja ga zove po imenu, da bi se poslije prikazala samo u viziji, dobivamo sliku punu dvojbenosti. Djevojka ostaje nedohvatnom i pjesma za svaku tvrdnju o njezinim namjerama donosi malo dokaza, a otvara niz mogućnosti tumačenja.

Ako je ženska osoba imala moć preobrazbe iz pastrve u djevojku, ako je znala subjektovo ime i ako je mogla iznenada nestati, znači da je imala nadnaravne sposobnosti. Moguće je pretpostaviti da se ona zapravo dala uhvatiti od subjekta, da je on za to zaslužan znatno manje od nje. Ali, ako se dala uhvatiti, zašto je onda tako naglo otišla? Konačno, zašto mu ne pomogne i jednostavno se opet 
ne pojavi, kad je tako moćna? Jesu li joj namjere uopće bile časne? Ili ga je samo nadraživala i zapravo od početka varala?

Nadalje, već je u tekstu naglašeno da djevojka poručuje kako joj je stalo do muškarca jer ga zove po imenu. Riječ je skoro pa o tituli in abesentia, kojom ženska osoba zna izreći prisnost. Točno je da je pjesma napravila svoj magijski svijet, i da se na podlozi tih pravila zbivaju događaji. No, ipak oni imaju neke poveznice s običnom stvarnosti - a u njoj će se teško dogoditi da će djevojka upravo pri prvom susretu bilo komu iskazati milost i zazvati ga po imenu, ako nije riječ o površnosti. Kad ga je zazvala po imenu, zašto ga je napustila? Je li za to da bi igrala vječnu igru u kojoj muško mora biti pokretno i tražiti? Ako to jest tako, igra biva okrutnom, zapravo s njezine strane blatnom, jer je kazivač već ostario u potrazi, a ima ju zapravo samo u viziji. U pjesmi nema dokaza koji bi govorili da je djevojka spriječena javiti se subjektu ili se konačno i pojaviti.

»I will find out where she has gone «, kazuje subjekt u trećoj kitici, pa možda u drugom glagolu, povezanom s djevojkom, navješćuje njezino prezime Gonne. Tada bi leptiri (moths) podsjetili na ime Maud. Nema dokaza za tu tvrdnju.

\section{Uže metodički dio}

Slamnigov prijevod na hrvatski, uporabljiv i u srednjoškolskoj nastavi, dostupan je u antologiji 100 pjesnika svijeta. Tekst je korisno najprije pročitati na hrvatskom, a nakon interpretacije i na engleskom. Pjesmu je moguće interpretirati s učenicima prvoga razreda srednje škole, gdje bi bila primjerom ljubavne lirike u prvom polugodištu.

Učenike je moguće motivirati tako što će im se na prethodnom satu dati navod iz Shakespeareove drame Antonije i Kleopatra, koji je poslužio i kao epigraf ovoga članka. Uputit ce ih se da napišu svoj komentar razmjene misli dvaju ljubavnika i potkrijepe ga prikazom stvarne ljubavi za koju su čuli. Drugi bi način motivacije mogao biti iznos Yeatsovih životopisnih podataka, koji su ovdje pruženi, a iskaz bi uključivao čitanje izabranih dijelova iz književnikova djela Memoirs te iz Cooteove biografije.

Pri nadahnutom govoru napamet i pri interpretativnom čitanju valja imati na umu sve vrijednosti govorenoga iskaza. Ton mora biti ozbiljan na početku sa spomenom vrućice u glavi, mora zasjati u izgovoru određenom prednjim dijelom govornoga aparata i nešto višim registrima pri pojavi djevojke, i mora izreći razočaranje u padu intonacije u njezinu nestanku. Modulacija staroga čovjeka koji kazuje treću kiticu mora imati ozbiljan, sonoran ton u prvim dvama stihovima završne kitice. Konačno, slike koje zapravo govore o određenoj konzumaciji, kad je govorna osoba s predmetom svoje želje, iako samo u viziji koju priziva, opet mora imati nešto od zadovoljstva, koje će se postignuti višim registrima glasa. Učenici mogu pisati i zadatke u kojima će pomno, izraz po izraz, stih po stih, opisati raspoloženja kazivača i s tim povezane stanke, modulacije i intonacije.

Interpretacija će uz standardni heuristički razgovor obuhvatiti čitanje navoda o broju osam iz Rječnika simbola, te zapise o zemlji, vodi, ognju i zraku iz istoga 
izvora ili iz Melchiorijeve knjige (Melchiori, 1960). Učenike valja prije sata pripremiti tako da neki od njih čitaju te teoretske zapise.

Stav djevojke moguće je, nakon uvodnih napomena ili razgovora, osmisliti tako što će učenice pisati prozni tekst u obliku sastavka, a možda i pjesme u prozi u prvom licu s djevojkom kao subjektom iskaza — što je provedivo u domaćoj zadaći ili u skraćenom obliku na samom satu. Učenice mogu izabrati djevojčin sućutan ili podrugljiv ton. Odluči li se nastavnik za raspravu, učenici moraju iznositi dokaze za svoje stavove iz samoga teksta. U razgovor može biti uključena i promjena naslova: pjesma koju govori bog ljubavi Angus - a njemu nitko ne može odoljeti - i pjesma koju kazuje luđak bitno se razlikuju i ako su im sve druge riječi iste.

Bitno je da učenici u svim vrstama teksta koje bi pisali prigodom interpretacije rabe motive iz Yeatsove pjesme: tako će pokazati da su djelo svladali, da razumiju razine značenja i smisao međuodnosa simbola. Učenicima je moguće zadati da odrede sličnosti i razlike u motivima između te pjesme i Nazorove $U$ trnjaku, o vili i Kraljeviću Marku.

\section{Zaključak}

»Pravo pjesništvo ne mora biti ni čudno ni tamno, nego može posjedovati prvotnu jednostavnost «(Bloom, 1970, 126). Hrvatski se čitatelj mora sjetiti Cesarićevih antologijskih tekstova. U Pjesmi lutalice Angusa naizgled nema teških mjesta, jer su njezini motivi jasno povezani, dapače tvore pripovijest i čvrst, ali jasan sustav. Brojne metodičke mogućnosti proizlaze upravo iz njezina jednostavna bogatstva. Pjesma je puna dubine i smisla, promišljeno rabi formalne vrijednosti u broju osam, figure simetrije i opetovnosti riječi, a svime sugerira vjeru subjekta u promišljen svijet — uspjeh potrage ipak ostaje otvorenim.

\section{Literatura}

Bloom, Harold (1970). Yeats. Oxford: Oxford University Press.

Carson, Donald A. (2007). A text without a context is a pretext. URL https://www.christianforums.com/threads/text-without-context-is-pretext.6141213 (24.03.2020.)

Chevalier, Jean; Gheerbrant, Alain (ur.) (1983). Rječnik simbola. Zagreb: Nakladni zavod Matice hrvatske.

Clark, David R. (1965). Metaphors for Poetry W. B. Yeats and the Occult. U: Robin Skelton i Ann Saddlemyer (ur.), The World of W. B. Yeats (str. 54 - 66). Dublin: Dolmen.

Coote, Stephen (1997). William Butler Yeats: A Life. London: Hodder and Stoughton.

Eliot, Thomas Stearns. Yeats. U: Thomas Stearns Eliot, Selected Prose of T.S. Eliot (str. 248-257). London: A Harvest Book.

Gjurgjan, Ljiljana Ina (1995). Mit, nacija i književnost "kraja stoljeća": Vladimir Nazor $i$ W. B. Yeats. Zagreb: Nakladni zavod Matice hrvatske.

Grgas, Stipe (1989). Nietzsche i Yeats. Zagreb: Hrvatsko filozofsko društvo.

Mazzari, Jerome L. (1957). Apple Imagery in Yeats' The Song of Wandering Angus. Modern Language Notes, 72(5), 342-343. 
Melchiori, Giorgio (1960). The Whole Mystery of Art. London: Routledge and Kegan Paul. Parkinson, Thomas (1952). The Sun and the Moon in Yeats's Early Poetry. Modern Philology, 50(1), 50-58.

Rudd, Margaret (1953). Divided Image. London: Routledge and K. Paul.

Sanesi, Roberto (1974). Introduzione. U: William Butler Yeats, Poesie (str. 13 - 63). Milano: Mondadori.

Squire, Charles (1996). Mythology of the Celtic People. Lonodn: Bracken Books.

Staiger, Emil (1946). Grundbegriffe der Poetik. Zürich: Atlantis.

Yeats, William Butler (1989). Poems of W. B. Yeats. Dublin: Gill i MacMillan.

An Interpretation and a Methodological Approach to the Poem, The Love Song of Wandering Angus by William Butler Yeats

Dean Slavić*

\section{Abstract}

The article explains the biographical background and structure of Yeats' poem, The Song of Wandering Angus. Although biography is significant to the poem, and the sources are well known, the final meaning of the poem, regarding the identification of the girl in the text, remains ambiguous. In the interpretation of the poem elements of the love poetry of quest, consummation and separation, are used stressing significant shifts revealed in changes in the title. As for the structure of the poem, the significance of repetition (floor, hazel, lands, fire...) is analyzed. The role of the symbols of light, symmetry and the number eight is also examined.

In the classroom students may be motivated by reading their own short essays on lines from Shakespeare's Anthony and Cleopatra - which also constitute the epigraph of this paper. It is useful to explore the poem, line by line, by assessing the subject's feeling and voice modulation during the stage reading. Methodology could also include debates on the trout-girl's attitude. The exercise may be consolidated in the writing of an essay or a prose poem by having students use motifs from the poem in their texts. Students could also read extracts from Yeats' memoires and critical essays in their interpretation of the interrelation of motifs.

Key words: William Butler Yeats; The Song of Wandering Angus; biography; structure; symmetry; methodological approach

* Dean Slavić, Ph.D., Full Professor, Faculty of Humanities and Social Sciences, University of Zagreb. Address: Ivana Lučića 3, 10000 Zagreb, Croatia. E-mail: dean.slavic@gmail.com 